\title{
絵画空間の図学
}

\section{小山 清男}

絵画は 2 次元の造形である。けれども通常その 2 次元 の画面内に，仮象的に 3 次元が描かれる。その仮象的な 空間の表現が，画面の構造となっており，一つの独立し たタブロオを支えている。古来画家たちは，そのような 絵画の骨組みとしての仮象的な空間を, どのように描出 しようかとさまざまに腐心してきた。1420年代のある日， イタリア，ルネサンス初頭の建築家として著名なブルネ レスキは, フィレンツェ, 花の聖母寺の入口から, それ に正対して立つ八角形プランの聖ジョヴァンニ洗礼堂を スケッチした。それが線遠近法, 図学的にいえば透視投 象の基本の発見であるとされ，程なくアルベルティはそ れを理論化し，透視投象の図法が成立したとされている。 このことは絵画史上画期的なことであった。ルネサンス の輝かしい数々の名作や, またそれ以降のヨーロッパ絵 画を, それ以前のものとはっきり一線を画して発展させ たのである。

直交する 2 枚の画面によって四つの象限を考える図学 的空間では, その第 1 象限に視点をおき, 直立する画面 を透して第 2 象限の空間と, そこに存在する人物や建築 などを画面上に投象しようとするのが透視投象である。こ の場合の第 2 象限は，上方と奥へ向って無限に開かれた 空間である。そこに何も存在していなければ, はるかに 広がる無限の空間をみることができ, 画面上に視点の高 さに引かれた 1 本の水平な直線が地平線であって, それ は広漠と広がる大地の面と, 頭上を高く覆う天空とを画 す線である。このように 2 次元の画面上に 1 本の水平な 直線を描くことによって, 無限の空間をあらわすことが できること，そのことこそ透視投象独自の視覚の世界で ある。ブルネレスキは, 眼前の八角形の洗礼堂を描くこ とによって，消失点を発見したと考えられているが，そ の消失点は直線の無限遠点の透視図であって, 広漠たる 空間の涯に見出される点である。

透視投象はこのように無限の空間を容易に表わすこと ができる。だが絵画空間を描こうとする場合，その無限 の大地一一地平面上に存在するさまざまなものの位置を，
画面上に正しく定めることができるということが一そう 有効なのである。地平面上に存在するもの一人物や動物, あるいは建物や器物などを，空間的存在として矛盾なく 2 次元の画面に定着することができるのである。すなわ ち透視投象は絵画制作の過程で，その絵画空間を定め，そ の中に建物や人やものなどを適切に配するための基礎的 な技法として用いられる。ルネサンスの画家たちは，こ の理論に基づく図法を駆使して制作したものと思われる。 フラ・アンジェリコのフィレンツェ, サン・マルコ修道 院の「受胎告知」の壁画，ピエロ・デルラ・フランチェスカ のアレッツォ, サン・フランチェスコ寺内陣の「聖十字架 物語」, そうしてかの有名なレオナルドの「最後の晚餐」図 などは，おそらくは透視投象の図法によって，その基本 的構造が決定されたのであろう。そのことは同時代の他 の多くの画家についてもいえることである。

この透視投象の図法を逆に用いることによって, 絵画 にあらわされた仮象的空間を，客観的な形に還元してみ ることができる。すなわち絵画作品の図学的分析である。 作図によってそれを求めてみると，絵画空間がどのよう な奥行を持っているか，またそこに配された建物や人物， あるいは調度や器物の大きさや空間的な位置などが明ら かになる。絵画を前にして想像していたよりも, はるか に奥行が深いことがあったり，またその逆のこともある。 あるいはまた，時として図法的に不合理な部分が見出さ れることもあろう。そのような部分にこそ絵画構成上の 微妙な問題が含まれていることもあり，単に図法上の誤 りとして捨て去ってはならない。それがその作品の美的 なものと密接に関連しているかも知れないからである。

美術史では，絵画はまずその内容としての主題が問わ れるであろう。ついでその主題が具体的にどのように表 現されているか, 形態や色彩, 材料やマチエールなど, 描 写技術が検討される。そうしてそれらが，画面上でどの ように配列されているかということ，すなわち構図につ いて述べられるであろう。構図という言葉は一般に，2 次元的な配列を意味するが，それはその絵画の中にあら 
わされている仮象的な空間，すなわち絵画空間と密接に 関連する。絵画空間と無関係な構図というものはあり得 ないといってもよい。というよりは構図は画面にあらわ された空間から，必然的に決定されるものである。また 逆にいえば，ある構図を作り上げるためには，どのよう な仮象空間を設定すればよいかということでもある。い ずれにしても絵画空間の設定ということは，画面を構築 するための，もっとも基本的な課題である。そうしてル ネサンス以後，それは主として透視投象によってなされ てきたのであった。

19世紀末から絵画はさまざまに変貌する。印象派は色調 に新たな視覚を導入し, 固有色を排して刻々に移り変わ る仮現色を画面上に表現することを目指すようになった。 モネの「睡蓮」の図などがそれである。そのためにルネサン ス以来の確固とした空間の表現は二義的なものとなった。 しかしそれでも透視投象は, 画面の構造を陰ながら支え ているといえよう。20世紀はじめにピカソやブラックによ って創始されたキュービスム(立体派) は，ルネサンス以 来の透視投象的空間の表現を，真向うから否定するもの であった。彼らの主張するところは, 絵画は 2 次元の造 形であるから，そこに仮象的に 3 次元をあらわそうとす ることは欺瞞であるとしたことである。キュービスムの 絵画は空間をあらわそうとはせず，ものを描こうとする。 しかもその描写の対象としての人や楽器や器物などを, 分 解してそれらの断片を 2 次元的に再構成することによっ てタブロオを創造しょうとしたものである。それはいわ ば絵画の革命とでもいうべき運動であったが, それによ って透視投象的な絵画空間が，すべて死滅してしまった 訳ではない。ピカソ自身にしても程なくキュービスム的 方法から脱して, いわゆる新古典主義的な作風に移って いる。そうしてその後一そう奔放な形の変貌を遂げるよ うになる。晚年の大作「ゲルニカ」では, 人物や動物などの 形は, キュービスム以後の独自のデフォルマシオンによ って描かれているけれども，それらの配されている舞台 となる空間はそれほど不思議なものではなく，ある程度 透視投象的な絵画空間となっていて, 図学的な分析の可 能なものとなっている。シュールレアリスムでは，初期 には無意識的な方法, すなわちオートマティスムによる 作画が盛んであったけれども, 後期にはサルヴァドル・ダ リなどは，意識的な技法をすすんで導入して制作するよ うになる。彼は精緻な技法を駆使して縹渺とした無限の 空間をあらわすことも多く，そこに奇異なものを配する ことによって, 超現実的な情景が創造されるのである。と
くに比較的晚年の「磔刑」図や,「ポルト・リガトの聖母」図 などは, 古典的な透視投象的空間が描かれている。それ らの作品は図法的に正確であって, 図学的分析に耐える ものである。以上のように透視投象によるヨーロッパ絵 画の分析は, 作品の基本的な構造を明らかにして, それ ぞれの史的，あるいは美的な考察を支えることにもなる。 ルネサンス的線遠近法一透視投象の理論が浸透しなか った日本の絵画では，どのような絵画空間が描かれてき たのであろうか。大和絵や絵巻などにみる建物の表現は, 図学でいう斜投象的な形となっている。斜投象は地平面 上にある建物を, 斜め上方から俯瞰する形に近い。ただ その場合の視点は無限の遠方にあると考えるから, 平行 な直線はつねに平行にあらわれる。斜め上から見るので あるから, 建物を描けばその屋根が大きくあらわれるが, 室内の情景はみえないことになる。そこで建物の屋根や 天井を取り払って室内がみえるように，吹抜屋台という 独自な描法が創案された。このような形状を図学的に分 析してみると，たとえば絵巻ではストーリーの進展と斜 投象的表現との関連のうちに思いがけず発見されるもの もある。また平安後期から鎌倉時代にかけて多く制作さ れた浄土曼茶羅では，斜投象的描法で弥陀を中心とする 浄土空間が整然と描かれている。斜投象の図法は，透視 投象の図法と並らぶ，絵画空間を描出するもう一つの図 学的理論体系であるといえよう。

透視投象，あるいは斜投象の図法は，東西の絵画史の 流れの中で，陰に陽に絵画空間を支えてきたのである。本 来図学は, ガスパール・モンジュのいうように，2次元 の平面上に 3 次元のものの形を正確にあらわす方法を考 究しょうとするものである。それは絵画制作の過程と重 なり合う部分も大であるのは当然であろう。またそれは, 画面の中にどのような仮象空間が秘められているかを知 るための方法を与えてくれる。図学の一つの分野として, 絵画を分析してその絵画空間を明らかにしてみようとす る領域があっても不思議ではない。それは美を探求する とき，あるいは絵画史を考えようとするとき，今まで見 逃されてきた問題を明らかにする據りどころともなるで あろう。

こやまきよお 東京芸術大学名誉教授 